Trivium: Estudos Interdisciplinares, Ano XIII, Ed. 2. p. 37-48.

http://dx.doi.org/10.18379/2176-4891.2021v2p.37

\title{
Uma abordagem psicanalítica do casal familiar em disputa judicial em torno da criança
}

Eduardo Ponte Brandão*

\section{Resumo}

O atendimento às famílias em situação de conflito judicial é de tamanha complexidade que exige uma interpretação para além do campo do direito, para a qual a psicanálise pode proporcionar grandes contribuições. O entusiasmo de Freud em relação ao recasamento não se aplica ao nosso tempo, sobretudo, diante dos casos de famílias divorciadas e recompostas que disputam judicialmente os seus filhos. A noção de casal familiar em Lacan fornece subsídios para a interpretação e o atendimento de famílias em litígio, cuja dialética do desejo e de gozo fornece as pistas para a união e a desunião do casal que deu origem à criança.

Palavras-chave: CASAL FAMILIAR; LITÍGIO; PAI; MÃE; CRIANÇA.

\section{A psychoanalytical approach of the family couple in a court dispute around the child}

\begin{abstract}
The assistance to families in situations of legal conflict is of such complexity that it requires an interpretation beyond the field of law, to which psychoanalysis can provide great contributions. Freud's enthusiasm for remarriage does not apply to our time, especially when faced with cases of divorced and recomposed families that dispute their children in court. The notion of family couple in Lacan provides subsidies for the interpretation and care of families in dispute, whose dialectic of desire and jouissance provides clues for the union and disunion of the couple that gave rise to the child.
\end{abstract}

Keywords: FAMILY COUPLE; LITIGATION; FATHER; MOTHER; CHILD.

\section{Une approche psychanalytique du couple familial en conflit juridique autour de l' enfant}

\section{Résumé}

L'assistance aux familles en situation de conflit juridique est d'une telle complexité qu'elle nécessite une interprétation dépassant le champ du droit, à laquelle la psychanalyse peut apporter de grandes contributions. L'enthousiasme de Freud pour le remariage ne s'applique pas à notre époque, surtout face aux cas de familles divorcées et recomposées qui disputent leurs enfants au tribunal. La notion de couple familial chez Lacan fournit des subsides à l'interprétation et à la prise en charge des familles en conflit, dont la dialectique du désir et de la jouissance fournit des indices sur l'union et la désunion du couple qui a donné naissance à l'enfant.

\footnotetext{
${ }^{*}$ Psicanalista. Psicólogo Tribunal Regional do Rio de Janeiro (TJ-RJ)

ORCID ID: https://orcid.org/0000-0003-3773-6575

E-mail: eduardopbrandao@gmail.com
} 


\section{Mots clés: COUPLE FAMILLIAL; CONTENTIEUX; PÈRE; MÈRE; ENFANT.}

O atendimento das famílias em situação de conflito no qual os pais disputam judicialmente a guarda e a convivência dos filhos requer outros olhares que não sejam exclusivos ao campo do direito. Tais famílias já buscam elas próprias resolverem seus impasses através da semântica do direito, a ponto de se dizer normalmente que suas relações são judicializadas. A judicialização dos laços amorosos desfeitos entre os amantes, assim como dos laços entre pais e filhos, obedece, porém, a uma lógica binária e maniqueísta, comum às ações judiciais, nas quais um dos genitores costuma acusar o outro de negligência, abuso do poder familiar ou de atos violentos contra a prole. A despeito dos esforços empreendidos pelos atores do judiciário para pacificar tais conflitos, as partes litigantes perseveram na hostilidade de uma contra a outra. Nessa espiral de acusações incessantes, encontramos frequentemente a criança e/ou o adolescente em situação de sofrimento e angústia que terminam por apresentar sintomas diversos, quando não passam diretamente ao ato. Para agravar a situação, a expressão de sofrimento e sintoma da criança não tem como efeito o fim do litígio dos pais, ao contrário, a aprofunda ainda mais, haja vista passarem, agora, a acusar um ao outro de ser o agente causador do mal-estar da criança. Por fim, há algo de excesso pulsional que une esse casal separado através do conflito judicial, frente ao qual a criança responde com seu sintoma e revela a sua mais profunda alienação ao Outro, seja representado por um de seus pais seja pelo campo do Judiciário (Brandão, 2019).

Frente a esse panorama, buscaremos o aporte da psicanálise para promover novas reflexões sobre as famílias em conflito que chegam ao Judiciário, assim como formas de intervenção distintas daquelas que são requisitadas por magistrados a suas equipes técnicas (p.ex., a produção de laudos e relatórios periciais). Seguindo esse raciocínio, iniciaremos uma breve investigação sobre a concepção de casamento, separação e recasamento em Freud, tendo como fio condutor os seus questionamentos sobre a feminilidade.

\section{Casamento e recasamento em Freud}

Sabemos que Freud colaborou para afrouxar as amarras da psicopatologia médica e dos ideais vitorianos de família que constrangiam as mulheres de seu tempo, impulsionando movimentos sociais de liberação sexual que marcaram as décadas seguintes à invenção da psicanálise. Entretanto, o campo da feminilidade era fon te de embaraço para Freud. É conhecido o célebre episódio em que ele admite a Marie Bonaparte que não chegou a resultados satisfatórios depois de pesquisar a sexualidade feminina por três décadas, perguntando-se, "afinal, o que quer a mulher?" (Gay, 1989).

Nesse contexto, Freud introduz tardiamente uma novidade, apresentando-a como uma descoberta arqueológica no texto Sexualidade Feminina (1931) e, em seguida, na conferência A Feminilidade (1933). A saber, de que nas mulheres "quase tudo o que encontramos na ligação do pai já estava presente na relação originária com a mãe" (Freud, 1933/2018, p. 322). A fase pré-edipiana tem nas mulheres importância maior que para os homens, de modo que a menina responsabiliza sua mãe por sua falta fálica e não a perdoa por tal desvantagem. A hostilidade da mulher em relação à mãe não provém da rivalidade edipiana, mas da fase precedente ao complexo de Édipo que, por sua vez, a reforça e a explora. $\mathrm{O}$ abandono do objeto materno pela menina e o encaminhamento da libido para o pai não significa, contudo, uma simples troca de objeto, pois ocorre sob o signo do ódio que "pode tornar-se extremo e durar a vida toda" (Freud, 1933/2018, p. $325)$. 
A intensidade da raiva da menina em relação à mãe corresponde à intensidade do amor que a precede, cuja demanda é ilimitada, ambivalente e, por fim, condenada a terminar em decepção e hostilidade. Donde Freud observa na experiência clínica que certas mulheres permanecem fixadas nessa experiência infantil sem nunca alcançarem uma verdadeira mudança em relação aos homens. Assim, alguns fenômenos da vida sexual feminina são remetidos a essa fase pré-edípica, especialmente nos casos em que mulheres escolhem maridos enquanto substitutos paternos quando, na verdade, herdam consigo a relação com sua mãe. A ligação originária da mulher com a mãe constitui a base da relação edipiana com o pai e, no casamento, vem à tona sob forma de infelicidade conjugal. Trata-se de uma parte do gozo do sujeito cuja resolução Freud curiosamente esperava que a mulher encontrasse numa segunda núpcia (Freud, 1933/2018).

Ora, por que Freud acredita que o segundo casamento seja uma saída da insatisfação feminina, já que remete a uma experiência arcaica da mulher com sua mãe?

Senão vejamos. O problema jurídico do divórcio já se colocava no final do século XIX, frente ao qual Freud pensava como um liberal (Iannini; Tavares, 2018). Ele mostrava-se sensível à pobreza libidinal que eram conduzidas as mulheres de seu tempo, constatando que o casamento nos moldes vitorianos as destinava à infelicidade. Como escrevera antes em Psicologia das Massas e

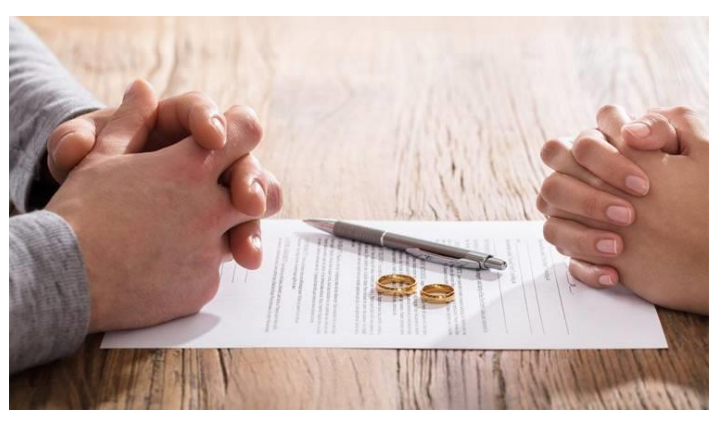
Análise do Eu (1921), "a oposição entre psicologia individual e psicologia social ou das massas (...) perde boa parte de sua nitidez se examinada a fundo" (Freud, 1921/2020, p. 137). Assim, não desconsiderava a importância da norma social na subjetivação da sexualidade. Por essa razão, na conferência sobre a feminilidade, considera que a possibilidade de a mulher escolher entre metas passivas e ativas depende de modelos de vida sexual mais amplos ou mais limitados, concluindo que "devemos (...) atentar para que a influência das normas sociais não seja subestimada, normas que, de forma semelhante, forçam a mulher para situações passivas" (Freud, 1933/2018, p. 317-8).

Em Moral Sexual Civilizada e Doença Nervosa Moderna (1908), Freud faz duras críticas à organização social que constrange a sexualidade nos limites da procriação matrimonial. Ao lançar mão de artifícios para impedir a concepção, o casal renuncia ao sexo e mantêm um tipo de casamento que, no fim das contas, "continua a exercer sua influência sobre os poucos filhos, ou o filho único, gerado pelo mesmo" (Freud, 1908/1996, p. 185). Do lado das mulheres, as restrições eróticas e as desilusões conjugais fazem com que transformem o filho num objeto sexual privilegiado ou contraiam grave neurose, por meio da qual poderiam se desforrar sobre os maridos. A infelicidade conjugal pode tornar-se uma poderosa fixação do sujeito ao gozo masoquista, cujo sofrimento chega a ponto de substituir o sofrimento psíquico e, assim, se constituir como obstáculo à direção da cura psicanalítica (Freud, 1924/1996).

Com intenção de se livrar da neurose de suas esposas que embotava a prometida felicidade conjugal, os maridos levavam-nas a Freud que, a esse respeito, diz: "Logo que a mulher se livra de suas inibições neuróticas, resolve acabar o matrimônio, que se mantinha apenas com a premissa de sua neurose" (Freud, 1920/2011, p. 105-6).

Tal observação clínica demonstra como a psicanálise se colocava ao lado das mulheres para fazer frente à dominação do patriarcado familiar. Elas recebiam educação virginal e depois que eram autorizadas por suas famílias para o casamento, tornavamse anestesiadas sexualmente. Seguindo os moldes da educação vitoriana, a autoridade 
dos pais acarretava a supressão da sexualidade da mulher que, para cumprir as regras morais da abstinência, lançava mão da masturbação clitoridiana. A frigidez feminina durante o casamento estaria associada, por consequência, à fase fálica e de certo modo corresponderia a uma vingança contra o marido não amado. É o que Freud desenvolve na terceira de suas Contribuições à Psicologia do amor (1917), onde ele explica por que a resolução dos conflitos conjugais poderá ocorrer num segundo casamento. Para Freud, a hostilidade da mulher em relação ao homem pode se disfarçar através da insatisfação conjugal, correspondendo a uma fixação infantil na fase fálica, articulada à inveja do pênis (penisneid). A frigidez é uma vingança inconsciente que tem como base o desejo feminino de emancipação em relação ao pai. A segunda núpcia corresponderia, então, à colocação em ato da emancipação feminina, já que o complexo de Édipo na mulher não estaria fadado à dissolução tal como ocorre no menino.

Como vimos acima, porém, a inveja fálica adquire outra significação a partir da descoberta de Freud a respeito de sua relação arcaica com a mãe. Dessa forma, causa estranheza que persista o seu ligeiro entusiasmo pelo recasamento enquanto resolução dos conflitos edipianos. Seria a segunda núpcia um ato tão poderoso que desvencilhe a mulher não só de seu pai, como também de sua fixação pré-histórica à mãe?

Deixemos por ora a questão em aberto. O fato é que temos melhores condições, em pleno século XXI, para observar os efeitos de casamentos e recasamentos sobre a subjetividade de nossa época.

Sabemos que o segundo casamento a que Freud aludia é legitimado desde algumas décadas em boa parte do Ocidente, chegando a serem mais frequentes as famílias recasadas, cujos filhos convivem com irmãos de relacionamentos anteriores de seus pais ou de suas madrastas ou de seus padrastos, do que a tradicional célula familiar pequenoburguesa. As transformações sobre as alianças amorosas e familiares aceleram-se desde a metade do século passado, com impactos inimagináveis sobre as leis jurídicas. Para citar o exemplo brasileiro, começando com o Estatuto da mulher casada de 1962 e a Lei do Divórcio em 1977, tivemos em seguida diversas leis relevantes de jurisdição direta ou indireta sobre as famílias que, nos últimos anos, passaram a surgir em períodos de tempo cada vez mais curtos: Constituição Federal (1988), o Estatuto da Criança e do Adolescente (1990), o Código Civil Brasileiro (2002), a Lei n. ${ }^{\circ}$ 11.340/2006, popularmente conhecida como Lei Maria da Penha, as leis sobre Guarda Compartilhada (Lei n. ${ }^{\circ}$ 11.698/2008 e a Lei n. ${ }^{\circ} 13.058 / 2014$ ), a Lei da Alienação Parental (Lei n. ${ }^{\circ}$ 12.318/2010), o Código de Processo Civil (Lei n. ${ }^{\circ}$ 13.105/2015), a Lei da Mediação (Lei n. $\left..^{\circ} 13.140 / 2015\right)$, a Lei que estabelece o sistema de garantia de direitos da criança e do adolescente vítima ou testemunha de violência (Lei n. ${ }^{\circ}$ 13.431/2017), entre outras (Conselho Federal de Psicologia, 2019).

A aceitação legal não somente do divórcio e do recasamento, assim como o reconhecimento estatal de diversos arranjos (famílias recompostas, adotivas, homossexuais etc.) como entidade familiar, é, sem dúvida, resultado central de conquistas sociais que marcaram as últimas décadas. A pluralidade de uniões amorosas e de composições familiares é expressão do desejo e dos afetos, cujas trilhas organizam na vida de cada sujeito aquilo que Kehl (2003) denomina de famílias tentaculares. A experiência de atendimento às famílias em litígio, contudo, conforme descrita acima, não nos deixa enganar: não há motivos para compartilharmos o mesmo entusiasmo de Freud em relação às segundas núpcias. Muitas dessas famílias que eternizam os seus conflitos no judiciário são oriundas de casais que tiveram as segundas núpcias ou passaram por diversos relacionamentos anteriores. Desse modo, a separação e o divórcio não são suficientes para desvanecer o gozo que mantém o sofrimento neurótico, especialmente, quando há disputa judicial em torno de um filho. Em muitos casos, a separação do casal 
familiar instaura uma crise que se perpetua por meios judiciais, a despeito de cada qual refazer a sua vida amorosa e ter o reconhecimento legal desta nova união. No campo judiciário, o leitmotiv da manutenção do conflito entre o casal familiar divorciado são, via de regra, os filhos.

$\mathrm{O}$ atendimento às famílias em litigio enlaça a dimensão pública e privada e, até certo ponto, o registro das leis jurídicas e da lei simbólica que articula o sujeito à cadeia geracional e, por assim dizer, à parentalidade. Rosa (2020) assinala que a parentalidade é fruto de operações constituídas a cada nascimento de um filho, cujo processo leva em conta, como dissemos, tanto a dimensão pública (política) quanto a privada (família). Nessa mesma linha de raciocínio, Iaconelli (2020) indica que a abordagem da parentalidade a partir da psicanálise coloca em primeiro plano "a importância de escutar como a angústia emerge no fenômeno parental de cada sujeito, de um lado, e as respostas que a cultura tem produzido diante desse fenômeno em nossa época, de outro" (Iaconelli, 2020, p. 16). Com efeito, buscaremos agora a partir de Lacan o aporte teórico para refletir sobre a dialética do desejo e do gozo posta em ação na união e na desunião do casal familiar, sobretudo, quando persevera o sofrimento associado a disputas judiciais em torno dos filhos. Para tanto, convém debruçarmo-nos sobre a noção de casal familiar em Lacan.

\section{O casal familiar em Lacan}

Até os anos 70, Lacan distinguia a posição masculina e feminina através da dialética fálica, mantendo-se fiel ao pensamento de Freud, segundo o qual a primeira posição sexual do ser humano, independente da anatomia, é considerada 'masculina' em vista da primazia do falo. Em seu retorno aos textos de Freud, Lacan leva às últimas consequências tal premissa, transformando o falo no significante que organiza o desejo humano. Logo, a relação entre os sexos regula-se pela dialética de ser ou ter o falo, cuja significação permite os seres falantes a se posicionarem diante do desejo do Outro.

A dialética fálica implica uma questão vital para o sujeito, a saber, desejar o desejo do Outro. A criança enquanto sujeito do inconsciente busca um lugar no desejo do Outro que, via de regra, se faz representar na pessoa da mãe. O desejo materno é a força motriz de entrada da metáfora paterna para a criança. Donde a inscrição da Lei paterna não ocorre através da mera imposição de um limite externo à mãe e sim a partir de seu próprio desejo. O que significa dizer que não há lei jurídica que por si só seja suficiente para modificar a relação da mãe com seu desejo. A introdução da criança na significação fálica depende menos de uma lei externa à mãe do que do fato de ser castrada simbolicamente.

Por ser castrada, os cuidados maternos dispensados à criança não devem tamponar o seu desejo enquanto mulher.

Por sua vez, a criança, alienada ao desejo do Outro materno, procura colocar-se como objeto desejável em sua própria fantasia e acena para a mãe enquanto falo imaginário. Ela pode até mesmo apaziguar a mãe por certo momento, mas jamais saciará o insondável desejo que habita o Outro materno. Ainda assim, há sempre o risco de se tentar realizar "esse casal mãe-filho feliz que se entende perfeitamente, contrariamente ao casal que a mãe faz com seu marido" (Melman, 2005, p. 46). Tal estado de coisas pode permanecer por muito tempo, às vezes por toda a vida, no sentido contrário do corte que separa a criança do Outro materno e a faça aceder à vida adulta. Melman adverte que há aquelas mães que não querem ser privadas do filho e se embarcam num amor intenso como meio de protegê-lo da inconsistência do Outro. Nesse sentido, "essa mensagem da 
mãe vem no lugar de um Outro, do grande Outro que não quer nada de mim, que não me diz nada e no qual nenhum sentido me espera" (Melman, 2005, p. 47).

A inscrição da metáfora paterna para a criança realiza-se por intermédio do desejo da mãe que se dirige para aquele cuja palavra é valorizada para representar a lei simbólica, independentemente de ser o genitor biológico ou guardião legal. O pai é menos a figura do genitor do que um significante designado como Nome do Pai que barra o gozo incestuoso entre a mãe e a criança.

Tal concepção psicanalítica sobre o pai difere do modelo consanguíneo de paternidade que se inscreve sub-repticiamente nas leis e nas práticas jurídicas, quando, por exemplo, a lei 12.318/2010 define, em seu artigo $2^{\circ}$, alienação parental como "a interferência na formação psicológica da criança ou do adolescente promovida ou induzida por um dos genitores, pelos avós ou pelos que tenham a criança ou adolescente sob a sua autoridade, guarda ou vigilância para que repudie genitor ou que cause prejuízo ao estabelecimento ou à manutenção de vínculos com este". Quando o legislador considera o repúdio da criança ao genitor como sendo uma situação anômala, estaria levando em conta os seus aspectos simbólicos ou apenas a consanguinidade? E quando esse genitor não representa nenhuma função simbólica, será justificada a criança recusa da criança ou deve ela ser obrigada a conviver boa parte do seu tempo com aquele? Nesse caso, se ela mantém sua recusa, deverá o outro genitor ser condenado por ser um 'alienador', ou seja, pelo simples fato de exercer alguma 'influência' sobre a criança? Mas, se considerarmos a 'influência' como uma expressão variante da alienação simbólica da criança ao Outro, condição necessária para que num segundo momento ela possa se separar e se constituir como sujeito, estariam os tribunais condenando algo que se espera da travessia de todo ser falante? A imposição externa da lei jurídica poderia referir a função simbólica ao genitor biológico, já que é dele que, segundo a norma legal, a criança não está autorizada a repudiar? $\mathrm{O}$ fato de a criança manifestar a recusa num contexto de litígio dos pais significa necessariamente que o genitor-alvo de sua hostilidade não represente a função paterna? Por fim, forçá-la a conviver com ele a despeito de sua recusa assegura a permanência da função simbólica ou pode ter como efeito contrário colocá-la em questão? Como podemos perceber, são muitas questões que se abrem a partir das contribuições da psicanálise, porém, na dificuldade de responder a elas no presente momento, prossigamos com a démarche lacaniana sobre o pai, o falo e, em suma, o papel do casal familiar na constituição da criança como sujeito de desejo e de linguagem.

Segundo Lacan (1958/1998), o significante fálico é o que delimita a diferença sexual como tal, instalando uma posição inconsciente na qual o sujeito: 1) se identifica com o tipo ideal de seu sexo, 2) responde sem sérias perturbações ao seu parceiro ou a sua parceira, 3) se refere à paternidade ou maternidade simbólica. Não obstante, tal formulação revela-se insuficiente a Lacan no decurso de seu pensamento para dar conta da sexualidade feminina, abrindo caminho para as elaborações posteriores sobre o gozo não fálico. Por conseguinte, conduzido pelos questionamentos acerca do gozo feminino, Lacan apresenta nos anos 70 as fórmulas da sexuação, particularmente nos seminários 19 e 20 e no texto $O$ Aturdito.

Ao formular a partilha dos sexos através de duas posições distintas de gozo, Lacan aponta para um gozo além da mediação fálica, o gozo feminino. A divisão entre masculino e feminino corresponde a posições do sujeito passíveis de serem tomadas tanto por homens quanto por mulheres, não havendo ninguém que frequente exclusivamente o campo do feminino. Homens e mulheres necessariamente circulam pelo campo do gozo fálico, relacionando-se com o parceiro ou parceira no campo da fantasia que, por sua vez, consente em portar as vestimentas imaginárias do objeto causa de desejo. O sujeito torna- 
se desejável na medida em que concorda em carregar os objetos parciais que o outro lhe atribui em sua fantasia, sem que nenhum dos dois parceiros saiba qual esta é (Cardaci Brasil, 1999). Seguindo esse pensamento, o sujeito diante do outro - homem ou mulher - está sempre diante do Outro sexo (Coutinho Jorge, 2013).

Entre o masculino e o feminino, ou seja, entre o universal fálico e não todo fálico, não há relação sexual. Os gozos não se complementam. Nos embates amorosos, o sujeito situado do lado masculino pode ocupar a posição do sujeito desejante e portador do falo e, portanto, reduzir o parceiro sexual para gozar dele ou dela como objeto ou, ainda, brandir o falo cujo brilho atrai aquele ou aquela que circula pelo campo feminino. Por outro lado, o sujeito pode se colocar como objeto causa de desejo e "ocupar o lugar de A mulher que não existe atraído pela posição fálica da parceira ou do parceiro" (Quinet, 2019, pp. 35-6). Dito de outro modo, do lado masculino, o sujeito toma aquele ou aquela situada no campo feminino como objeto causa de desejo. Ele faz da mulher seu sintoma, ao passo que ela dá signos do inconsciente daquele que a escolheu. Por sua vez, a mulher encontra o significante de seu desejo no corpo de um homem, ou seja, reconhece-se como faltosa e endereça a um homem o significante que lhe falta.

Nesse bailado de desejos e gozos, a vinda de uma criança escancara a divisão do casal e, portanto, a não relação sexual. Vale destacar que a assunção do lugar de um Outro para o bebê já abre por si só a dimensão do real, impossível de simbolizar, pois conduz aquele ou aqueles que cuidam dele ao mistério e à estranheza do corpo - do bebê e do próprio (Garrafa, 2020). A partir do desejo particular do adulto que cuida do bebê, ele passa a encarnar um Outro que interpreta o seu corpo e suas manifestações, supondo nele um sujeito pleno de sentimentos, saberes e intencionalidades. A tentativa de decifrar o bebê esbarra, contudo, no que é inapreensível pela linguagem:

O encontro com essa dimensão indizível da existência, que remetemos ao conceito de 'real' em Lacan, não é prerrogativa da relação com um bebê; mas é, nela, marcante e inevitável. As versões da janela que se entreabre para o real na relação com um bebê variam, podendo passar por tudo o que a interpretação não recobre: o choro que não cessa, o sono que inexplicavelmente não se prolonga, o traço que se mostra irreconhecível na linhagem transgeracional ou, entre outras possibilidades, a nítida percepção de que o bebê é, antes e além de 'sua majestade', apenas um corpo estranho no ninho familiar (Garrafa, 2020, p. 63).

A invasão desse real indizível permite compreender o fato comum de a separação do casal ocorrer, em boa parte, às vésperas ou logo em seguida à vinda do bebê. Pela intensidade com que ocorre essa ruptura, os seus efeitos prolongam-se até a disputa judicial e se mostram refratários às decisões do magistrado.

A criança divide o casal familiar, não obstante, de modo diferente para cada lado que o constitui.

Do lado do pai, o sujeito coloca-se como barrado, o que implica em lidar com sua própria falta, com sua própria castração. É comum que o pai, com o nascimento da criança, se angustie com a questão sobre o que ela, a mulher, quer dele, ou seja, ele fica às voltas com o lugar que ocupa no desejo dela. Frente ao enigmático desejo do Outro, diz Miller (2014), "um homem (...) só se torna pai se aceitar o não-todo que constitui a estrutura do desejo feminino" (Miller, 2014, p. 9). Muitos homens, porém, parecem lançar-se numa roda viva de traições com a gravidez ou a concepção de um filho, como se pretendessem reafirmar a sua posição fálica.

Em contrapartida, "o amor materno não se sustenta na reverência pura à lei do desejo, ou que só se sustenta nele se uma mulher, enquanto mãe, permanecer, para um 
homem, a causa de seu desejo" (Miller, 2014, p.3). Nesse raciocínio, do lado materno a divisão ocorre entre a mulher e a mãe. Enquanto mulher, ela fica no lugar de objeto, ao passo que enquanto mãe, ela fique numa posição masculina por tomar a criança como objeto de seu desejo. Em outras palavras, é do lugar de mãe que a mulher tem acesso ao gozo fálico que vem fazer borda ao gozo não fálico da posição feminina (Pacheco, 2012). A criança dá à mãe aquilo que falta ao sujeito masculino: o próprio objeto de sua existência, aparecendo no real (Lacan, 1969/2003).

Cabe aqui a advertência de Miranda Junior (2020) sobre o risco de naturalizarmos a família de acordo com o modelo heterossexual e reprodutivo ao aproximarmos teoricamente função materna e mulher, de um lado e de outro, função paterna e homem. Nesse sentido, o autor reitera que, sob o viés lacaniano, homem e mulher devem estar referidos ao quadro da sexuação. Por sua vez, se a anatomia (macho / fêmea) tem alguma importância no posicionamento de cada ser falante diante do Outro sexo, não é ela que a define e sim o que cada falasser assentiu fazer com essa diferença. Função Paterna e Função Materna são designações de funções a serem exercidas e não têm relação direta com macho/fêmea ou homem/mulher. Qualquer falasser, homem ou mulher, macho ou fêmea, pode em termos estruturais ocupar o lugar do Outro que oferece cuidados à criança e permite a inserção do infans no universo simbólico. Isso implica também em dizer que não é necessariamente apenas um que representa tais funções simbólicas. A proposta lacaniana é que haja um desejo não anônimo, ou seja, atravessado pelo significante paterno que permite inserir a criança no circuito da demanda e das trocas e substituições simbólicas.

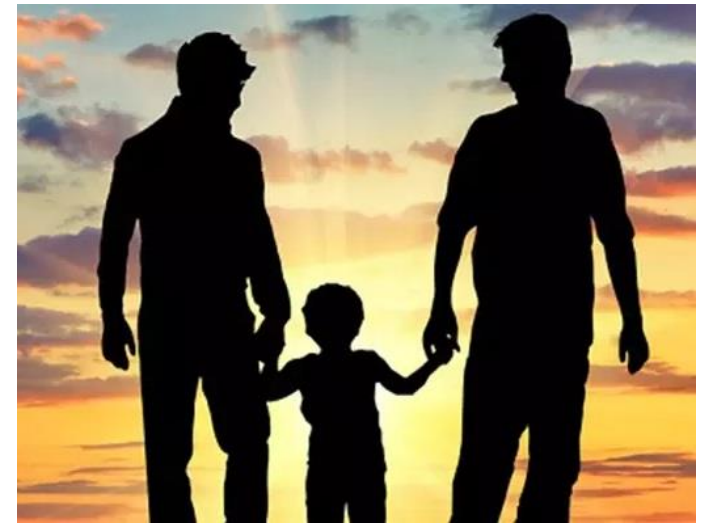

Garrafa (2020) assinala uma perspectiva semelhante ao destacar que a função materna não pertence necessariamente ao domínio da mãe, mesmo quando ela está presente na família. A partir do laço entre bebê e o adulto que dele se encarrega, fundamse relações entre o sujeito que se constitui e o Outro primordial do simbólico. A função materna exige forte trabalho psíquico, podendo ser exercida tanto pela mãe quanto pelo pai, pela avó, pela família acolhedora, pelo educador de serviço de acolhimento ou por qualquer outra pessoa. Tomar para si os significantes "mãe" e "pai" implica assumir uma posição na família, na sociedade e perante aquele que então passa a ser reconhecido como "fillho". Assim sendo, a função paterna, conforme já indicamos, também não pertence ao domínio do pai.

A nomeação de 'pai' ou 'mãe' costuma ser fonte de conflito nos litígios familiares quando p. ex. são atribuídos respectivamente ao padrasto ou madrasta da criança, sendo importante em casos assim a atuação das equipes interprofissionais que assessoram os juízes. Tais equipes lançam mão em suas avaliações técnicas das noções de pais e mães socioafetivos que, de certo modo, indicam algo da função simbólica paterna ou materna.

O simbólico não é apenas o que define a posição materna ou paterna, mas também o gozo. Para tanto, é importante avançarmos na teoria de Lacan, sobretudo, quando começa a dar ênfase nos anos 70 à dimensão do real. Com efeito, ele próprio coloca em questão a sua doutrina clássica da relação do sujeito com o falo, o Nome-do-Pai e, logo, com o Outro simbólico. O Nome-do-pai passa a ter relação não apenas com o falo, mas também com o objeto a. Assim, a relação entre pai e filho é concebida em termos de modelo da função-gozo e não mais como identificação edipiana e interdição, situando-se "para além da operação significante da metáfora paterna" (Quinet, 2015, p. 36). 
Em um de seus últimos seminários, mais precisamente no Seminário 22 - RSI (Lacan, 1974-1975/2017), Lacan traz uma definição inovadora sobre o que seria um 'pai': a saber, aquele que só tem direito ao respeito e amor se forem perversamente ou, por neologismo, 'pai-versamente', orientados por fazer de uma mulher a sua causa:

Um pai só tem direito ao respeito, senão ao amor, se o-dito amor, o-dito respeito, estiver, vocês não vão acreditar em suas orelhas, père-vertidamente orientado, isto é, feito de uma mulher, objeto pequeno a que causa seu desejo, mas o que essa mulher em pequeno acolhe, se posso me exprimir assim, nada tem a ver na questão. Do que ela se ocupa, são outros objetos pequeno a que são as crianças junto a quem o pai então intervém (...). Pouco importa que ele tenha sintomas, se acrescenta aí o da perversão paternal, isto é, que a causa seja uma mulher que ele adquiriu para lhe fazer filhos e que com estes, queira ou não, ele tem cuidado paternal (Lacan, 1974-1975/2017, p. 23).

Nesse sentido, um pai deve sua existência ao fato de enfrentar a questão do gozo de uma mulher e ter feito dela o objeto $a$ que causa seu desejo, levando-o a termo nos embates amorosos. A perversão paterna é definida quando a causa do desejo é uma mulher que, conforme a citação acima, ele adquiriu para fazer filhos e que com estes, queira ou não, ele tenha cuidado paterno: "É realmente surpreendente que", escreve Quinet, "Lacan diga que o pai é perverso quando este tem uma mulher como causa de desejo que será a mãe de seus filhos" (Quinet, 2015, p. 52).

A mulher ocupa o lugar de objeto a para o homem, ao passo que para a mulher o seu objeto é o filho. Dito de outro modo, se a mulher é tomada por um homem enquanto objeto causa de desejo, ela mesma, enquanto sujeito, toma a criança como objeto em sua fantasia, como vimos acima. Pai, mãe e filho são definidos a partir do objeto a.

Miranda Junior (2020) destaca que nessa assertiva de Lacan há uma aproximação estreita entre mulher e função materna. Porém, não se trata aquela de uma fêmea e sim da posição sexuada mulher, que inclui a abertura tanto para o gozo suplementar quanto o capricho mortífero. Assim, somente "o falasser na posição discursiva mulher, com seu capricho, exerceria a Função Materna ao colocar os filhos como objeto $a$ e endereçar ao parceiro (homem) seu desejo de falo" (Miranda Junior, 2020, p. 51), embora deixe em aberto outras questões como exemplo, da posição de homens celibatários que desejam adotar crianças.

De todo modo, a criança ocupa um lugar condensador de gozo, realizando a presença do que Lacan designa como objeto a na fantasia. "Ela", a criança, "aliena em si qualquer acesso possível da mãe a sua própria verdade, dando-lhe corpo, existência e até exigência de ser protegida" (Lacan, 1969/2003, p. 370). A criança empresta seu corpo para que a verdade do Outro goze através de seus sintomas, ao mesmo tempo que delimita o seu gozo desarrazoado (Soler, 2005).

Acreditamos que a dimensão do gozo não deve ser negligenciada nos embates familiares, sendo provavelmente a razão pela qual perseveram os embates judiciais em torno da criança. Nesse aspecto, cabe lembrar a atribuição principal do Direito assinalada por Lacan, não sendo outra coisa senão "repartir, distribuir, retribuir o que diz respeito ao gozo" (Lacan, 1972-3/1985, p.11).

\section{Conclusão}

A psicanálise introduz outros vieses de interpretação dos embates familiares em torno da criança que chegam ao Judiciário. Tais conflitos são interpretados à luz do 
Direito de forma empobrecida, pois, de modo geral, são vistos de forma maniqueísta e binária, quando não ocorre certa confusão entre os atributos biológicos e simbólicos.

Em contrapartida, a psicanálise introduz desde Freud a dimensão do gozo masoquista e da neurose na manutenção do casamento infeliz, surgindo de sua parte um ligeiro entusiasmo pelas segundas núpcias. A experiência de atendimentos às famílias em litígio, parte delas sendo recasadas, não nos deixa levar, contudo, pelo entusiasmo de Freud, talvez pela razão de que em sua época não fosse tão frequente e comum como é nos dias atuais.

A investigação teórica sobre a noção de casal familiar em Lacan permite vislumbrar tanto as funções simbólicas materna e paterna, não necessariamente representadas respectivamente por mães/fêmeas e pais/machos, quanto as posições sexuadas de gozo masculino e feminino, cuja impossibilidade de relação sexual lança novas luzes sobre as rupturas de casais por ocasião da vinda de um filho quanto pela perpetuação do litígio a despeito das decisões judiciais.

Acreditamos por fim que o aporte da psicanálise não encerra seus efeitos nos limites da reflexão teórica, mas que possa a partir da escuta e do ato analítico subverter o discurso dominante do Direito sobre os conflitos subjetivos de família que são tutelados pelo poder judiciário.

\section{Referências}

Brandão, Eduardo (org.). (2019). Psicanálise e Direito; subversões do sujeito no campo jurídico". Rio de Janeiro: Nau.

Cardaci Brasil, M. (1999). O anel que tu me deste. Em: ASSOCIAÇÃO PSICANALÍTICA DE PORTO ALEGRE (org.). O Laço Conjugal. Porto Alegre: Artes e Ofício.

Conselho Federal de Psicologia (2019). Referências Técnicas Para Atuação De Psicólogas(Os) Em Varas De Família / Conselho Federal de Psicologia, Conselhos Regionais de Psicologia e Centro de Referência Técnica em Psicologia e Políticas Públicas. 2. ed. Brasília: CFP.

Coutinho Jorge, M. A. (2013). O Real e o Sexual: do inominável ao pré-conceito. Em: Quinet, A. \& Coutinho Jorge, M. A. (org.). As Homossexualidades na Psicanalise; na história de sua despatologização (pp. 15-28). São Paulo: Segmento Farma.

Freud, S. (1996). Moral Sexual 'Civilizada' e Doença Nervosa Moderna. Em: Edição Standard Brasileira das Obras Completas de Freud, vol. IX. Rio de Janeiro: Imago. (Original publicado em 1908)

Freud, S. (1996). Contribuições à Psicologia do Amor. Em: Edição Standard Brasileira das Obras Completas de Freud, vol. XI. Rio de Janeiro: Imago. (Original publicado em 1917 [1918-1917]).

Freud, S. (2011). Sobre a Psicogênese de um caso de homossexualidade feminina. Em: Obras Completas v. 15; Psicologia das Massas e Análise do Eu e outros textos. Rio de Janeiro: Companhia das Letras. (Original publicado em 1920)

Freud, S. (2020) Psicologia das Massas e Análise do Eu. Em: Cultura, Sociedade, Religião; o mal-estar na cultura e outros escritos. Belo Horizonte: Autêntica. (Original publicado em 1921)

Freud, S. (1996). O problema econômico do masoquismo. Em: Edição Standard Brasileira das Obras Completas de Freud, vol. 19. Rio de Janeiro: Imago. (Original publicado em 1924) 
Freud, S. (2018) Sobre a Sexualidade Feminina. Em: Iannini, G \& Tavares, P. (org.) Amor, Sexualidade, Feminilidade. Belo Horizonte: Autêntica. (Original publicado em 1931).

Freud, S. (2018) A Feminilidade. Em: Iannini, G \& Tavares, P. (org.) Amor, Sexualidade, Feminilidade. Belo Horizonte: Autêntica. (Original publicado em 1933).

Garrafa, T. (2020) Primeiros tempos da Parentalidade. Em: Teperman, D. \& Garrafa, T. \& Iaconelli, V. (orgs). (pp. 55-70) Parentalidade. Belo Horizonte: Autêntica.

Gay, P. (1989) Freud: Uma vida para nosso tempo. São Paulo: Companhia das Letras.

Iaconelli, V. (2020) Sobre as origens: muito além da mãe. Em: Teperman, D. \& Garrafa, T. \& Iaconelli, V. (orgs). (pp. 11-22) Parentalidade. Belo Horizonte: Autêntica.

Iannini, G. \& Tavares, P. (2018) Sobre Amor, Sexualidade, Feminilidade. Em: Iannini, G \& Tavares, P. (org.) Amor, Sexualidade, Feminilidade. Belo Horizonte: Autêntica.

Lacan, J. (1998). A Significação do Falo. Em: Lacan, J. Escritos. (pp. 692-703) Rio de Janeiro: Jorge Zahar Editor. (Original publicado em 1958)

Lacan, J. (2003). Nota sobre a criança. Em Lacan, J. Outros escritos. (pp. 369370). Rio de Janeiro: Jorge Zahar. (Original publicado em 1969)

Lacan, J. (1985). O Seminário, Livro 20, Mais, Ainda (1972-1973). Rio de Janeiro, Jorge Zahar Editor.

Lacan, J. (Inédito). O seminário, livro 22: R.S.I. (1974-1975). Inédito. Acesso em 07 de agosto de 2021, de http://lacanempdf.blogspot.com/2017/03/o-seminario-22-rsijacques-lacan.html

Melman, C. (2005). Será que podemos dizer, com Lacan, que a mulher é o sintoma do homem? Rio de Janeiro: Tempo Freudiano.

Miller, J.-A. (2014). A Criança Entre a Mulher e a Mãe. Opção Lacaniana online nova série, 15, 1-15. Acesso em 07 de agosto de 2021, de http://www.opcaolacaniana.com.br/pdf/numero_15/crianca_entre_mulher_mae.pdf

Miranda Junior (2020). O exercício da Função Materna e o semblante mulher na tábua da sexuação de Lacan. Tempo Psicanalítico, Rio de Janeiro, v. 52.1, 38-60.

Acesso em 07 de agosto de 2021, de http://pepsic.bvsalud.org/pdf/tpsi/v52n1/v52n1a02.pdf

Pacheco,A. L. (2012) Da Fantasia de Infância ao Infantil na Fantasia - a Direção do Tratamento na Psicanálise Com Criança. São Paulo: Annablume.

Quinet, A. (2015) Édipo ao Pé da Letra; fragmentos de tragédia e psicanálise. Rio de

Janeiro, Zahar.

Quinet, A. (2019). A psicanálise na era trans. Em: A. Quinet, \& S. Alberti (org.). Sexuação e identidades (pp. 27-37). Rio de Janeiro, RJ: Atos e Divãs.

Kehl, M. R. (2003) Em Defesa da Família Tentacular. Em: GROENINGA, G. \& PEREIRA, R (Coord.). Direito de Família e Psicanálise; rumo a uma nova epistemologia. (pp. 163-176). Rio de Janeiro: Imago.

Rosa, M. (2020) Passa anel: famílias, transmissão e tradição. Em: Teperman, D. \& Garrafa, T. \& Iaconelli, V. (orgs). (pp. 23-38) Parentalidade. Belo Horizonte: Autêntica.

Soler, C. (2005) O Que Lacan Dizia das Mulheres. Rio de Janeiro: Jorge Zahar.

Lei 12.318/2010, de 26 de agosto de 2010. Acesso em 07 de agosto de 2021, de http://www.planalto.gov.br/ccivil_03/_ato2007-2010/2010/lei/112318.htm 
Citação/Citation: Brandão, E. P. (2021). Uma abordagem psicanalítica do casal familiar em disputa judicial em torno da criança. Trivium: Estudos Interdisciplinares (Ano XIII, Ed.2), pp. 37-48.

Recebido em: 08/08/2021

Aprovado em: 01/09/2021

Trivium: Estudos Interdisciplinares, Ano XIII, Ed. 2. p. 37-48. 